\title{
Gracilibacillus boraciitolerans sp. nov., a highly boron-tolerant and moderately halotolerant bacterium isolated from soil
}

\author{
Correspondence \\ Iftikhar Ahmed \\ iftikharnarc@hotmail.com \\ Toru Fujiwara \\ atorufu@mail.ecc.u-tokyo.ac.jp
}

\author{
Iftikhar Ahmed, ${ }^{1,2}$ Akira Yokota ${ }^{3}$ and Toru Fujiwara ${ }^{1,4}$ \\ ${ }^{1}$ Biotechnology Research Centre, University of Tokyo, Yayoi 1-1-1, Bunkyo-Ku, \\ Tokyo 113-8657, Japan \\ ${ }^{2}$ National Agricultural Research Centre, Park Road, Islamabad 45500, Pakistan \\ ${ }^{3}$ Institute of Molecular and Cellular Biosciences, University of Tokyo, Yayoi 1-1-1, Bunkyo-Ku, \\ Tokyo 113-8657, Japan \\ ${ }^{4}$ SORST, JST, Chiyoda-ku, Tokyo, Japan
}

Boron, a non-metal micronutrient, is required in various amounts by different organisms and is essential for the optimum growth of plants (Warington, 1923) and some animals (Rowe et al., 1998; Rowe \& Eckhert, 1999). Its essentiality for bacteria has been reported recently (Ahmed et al., 2007). A boron-containing quorum-sensing signal molecule is produced in several species of bacteria (Chen et al., 2002). The antibiotics boromycin (Kohno et al., 1996) and tartrolon A and B (Irschik et al., 1995), which are synthesized by bacteria, also contain boron. NegreteRaymond et al. (2003) described the catabolism of phenyl boronic acid in an Arthrobacter nicotinovorans strain, during

The GenBank/EMBL/DDBJ accession number for the 16S rRNA gene sequence of strain $T-16 X^{\top}$ is $A B 197126$.

SEMs of cells of strain $T-16 X^{\top}$, details of boron tolerance for strain $\mathrm{T}-16 \mathrm{X}^{\top}$ and related strains, parsimony and maximum-likelihood trees based on 16S rRNA gene sequences and results of TLC of polar lipids of strain $\mathrm{T}-16 \mathrm{X}^{\mathrm{T}}$ are available as supplementary material in IJSEM Online. which boron is predicted to be released as orthoboric acid $\left[\mathrm{B}(\mathrm{OH})_{3}\right]$.

At elevated levels, boron is toxic to living cells. Because of its toxicity, boron has long been used in the treatment of recurrent vulvovaginal candidiasis caused by some species of Candida and Saccharomyces (Swate \& Weed, 1974; Otero et al., 2002). Boron is used as a food preservative to sterilize against micro-organisms (Nielsen, 2004) and is also used as an insecticide against cockroaches (Cochran, 1995).

We screened and isolated several boron-tolerant species from a soil containing naturally high levels of boron from the Hisarcik area in the Kutahya Province of Turkey. This area has been reported to be naturally high in boron minerals (Çöl \& Çöl, 2003). The recently reported species 'Bacillus boroniphilus', isolated from this soil, can tolerate more than $450 \mathrm{mM}$ boron and requires boron for growth (Ahmed et al., 2007). From our samples, we characterized a novel bacterial strain, $\mathrm{T}-16 \mathrm{X}^{\mathrm{T}}$, that is moderately 
Table 1. Characteristics that differentiate strain $T-16 X^{\top}$ and closely related previously described species

Strains: 1, T-16X $\mathrm{X}^{\mathrm{T}}$ (Gracilibacillus boraciitolerans sp. nov.); 2, G. orientalis CCM $7326^{\mathrm{T}}$ (data from Carrasco et al., 2006); 3, G. dipsosauri DSM $11125^{\mathrm{T}}$ (unless indicated, data from Deutch, 1994; Lawson et al., 1996); 4, G. halotolerans DSM 11805 ${ }^{\mathrm{T}}$ (unless indicated, data from Wainø et al., 1999). +, Positive; -, negative; ND, no data. All strains produce spores in a terminal position.

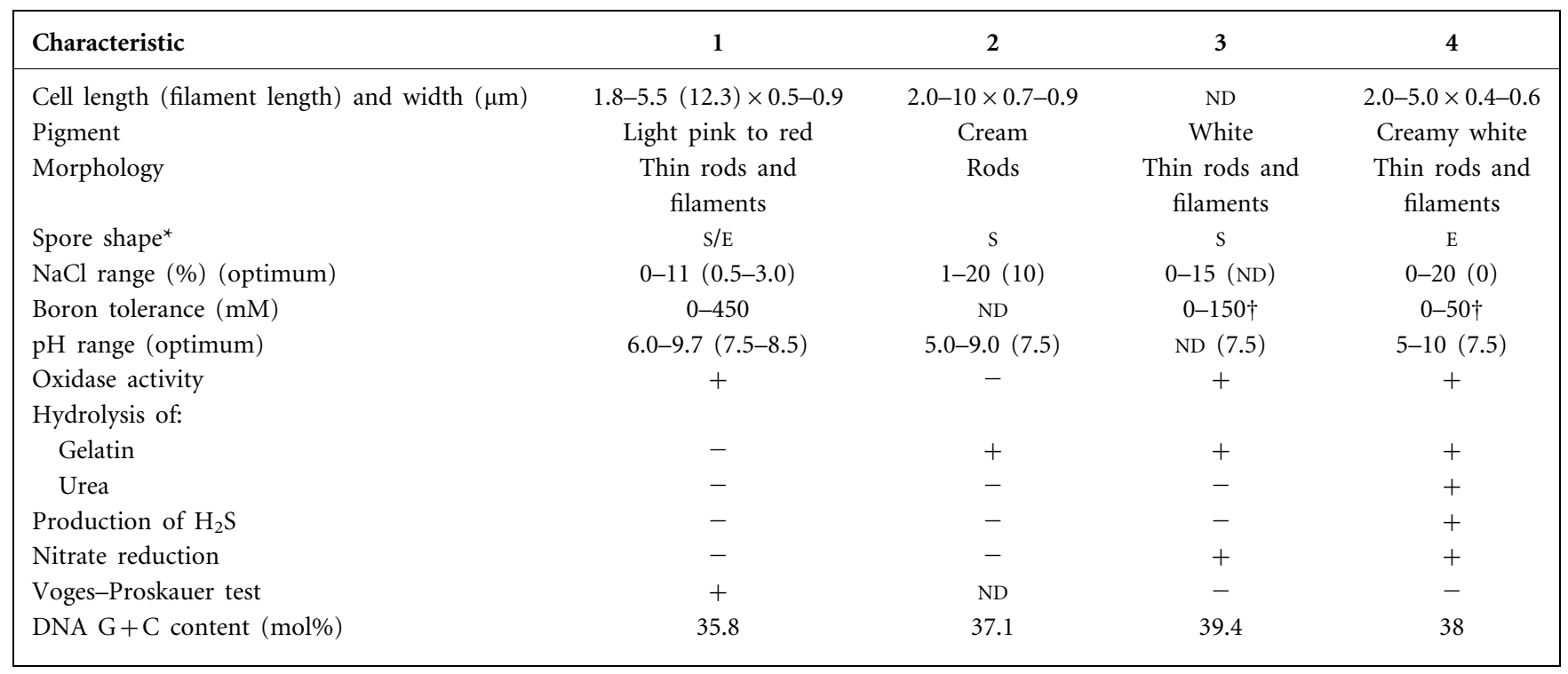

${ }^{\star}$ E, Ellipsoidal; s, spherical.

$\dagger$ Results from this study.

halotolerant and highly boron-tolerant. Based upon the data, we propose that the strain belongs to the genus Gracilibacillus. The genus Gracilibacillus was described by Wainø et al. (1999) and its three currently characterized species were isolated from extreme hypersaline environments.

We used previously described isolation and enrichment procedures to obtain strain $\mathrm{T}-16 \mathrm{X}^{\mathrm{T}}$ (Ahmed et al., 2007). The purified culture of the isolate was maintained on agar medium and also stored as a glycerol $(35 \%$, w/v) stock at $-80{ }^{\circ} \mathrm{C}$. Sporangia and the sizes of cells grown on LuriaBertani agar $(\mathrm{pH} \mathrm{7.0)}$ for 16 days were observed under phase-contrast microscopy, whereas flagella were observed using a scanning electron microscope according to a previously described procedure (Ahmed et al., 2007). It was clearly evident that individuals of strain $\mathrm{T}-16 \mathrm{X}^{\mathrm{T}}$ use a monotrichous flagellum (see Supplementary Fig. S1 available in IJSEM Online) for movement and produce endospores in a non-bulging or slightly swollen sporangium. Gram staining, performed according to Hucker's modified method (Cowan, 1974), revealed that the cells of strain $\mathrm{T}-16 \mathrm{X}^{\mathrm{T}}$ are Gram-positive.

The toxic effects of high boric acid concentrations on living cells are well known (Nable et al., 1997). The boron tolerance of strain T-16X $\mathrm{X}^{\mathrm{T}}$ was compared with that of Escherichia coli $\mathrm{DH} 10 \mathrm{~B}$ as a control, following the procedure described previously by Ahmed et al. (2007). Strain T-16X $\mathrm{X}^{\mathrm{T}}$ showed boron tolerance (Supplementary Fig. S2) because it grew in TSB medium ( $\mathrm{pH} 7.4 \pm 0.1$ ) containing $450 \mathrm{mM}$ boric acid
$\left(\mathrm{H}_{3} \mathrm{BO}_{3}\right.$, referred to simply as boron in this paper). In similar tests, we observed that the closely related strain Gracilibacillus halotolerans DSM $11805^{\mathrm{T}}$ tolerated up to $50 \mathrm{mM}$ boron, Gracilibacillus dipsosauri DSM $11125^{\mathrm{T}}$ up to $150 \mathrm{mM}$ boron and Paraliobacillus ryukyuensis IAM $15001^{\mathrm{T}}$ as much as $100 \mathrm{mM}$ boron. Among recently reported boron-tolerant species (Ahmed et al., 2007), 'B. boroniphilus' strains are reported to withstand more than $450 \mathrm{mM}$ boron and cannot survive in its absence. In contrast, strain $\mathrm{T}-16 \mathrm{X}^{\mathrm{T}}$ tolerated $450 \mathrm{mM}$ boron, but did not require it as an essential component for growth. Boron salts have often been used in microbial growth media (Stanier et al., 1966); however, the biological functions that require boron in plants and microbes are not clear, despite the fact that boron is required for growth in some organisms.

The ranges of $\mathrm{pH}, \mathrm{NaCl}$ concentration and temperature for growth of strain $\mathrm{T}-16 \mathrm{X}^{\mathrm{T}}$ were determined as described previously (Ahmed et al., 2007). Motility, catalase and oxidase tests, resistance to antibiotics and enzyme activities were also evaluated following procedures described previously (Ahmed et al., 2007). Various physiological and biochemical tests were carried out using API $50 \mathrm{CHB}$ and API 20E galleries (bioMérieux) according to the manufacturer's instructions. Physiological experiments using the API system, the determination of antibiotic resistance using ATB-VET and catalase and oxidase tests were repeated several times. The Biolog GP2 and GN2 characterization systems were used to determine various metabolic features according to the manufacturer's instructions. 
Strain T-16X $\mathrm{X}^{\mathrm{T}}$ was moderately halotolerant (Table 1) and highly boron-tolerant (Supplementary Fig. S2). The strain withstood $11 \%(\mathrm{w} / \mathrm{v}) \mathrm{NaCl}$ and grew optimally in the presence of $1-3 \% \mathrm{NaCl}$. Because it exhibited optimum growth at alkaline $\mathrm{pH}$ (range $\mathrm{pH}$ 7.5-8.5) and was able to grow at above $\mathrm{pH} 9.0$, it was characterized as alkalitolerant, according to the definition of Jones et al. (1994). The best growth occurred on BUG medium containing $20 \mathrm{mM}$ boron and $1 \%(\mathrm{w} / \mathrm{v}) \mathrm{NaCl}$, but we also observed growth on marine agar 2216 (MA; Difco), tryptic soya agar (TSA) and nutrient agar (NA), although growth was slow and colonies were small. Strain $\mathrm{T}-16 \mathrm{X}^{\mathrm{T}}$ shares many characteristics with members of the genus Gracilibacillus. The characteristics that differentiated strain $\mathrm{T}-16 \mathrm{X}^{\mathrm{T}}$ from closely related type strains are shown in Table 1. Additional characteristics are included in the species description. In addition to its boron tolerance, the major characteristic that differentiated strain $\mathrm{T}-16 \mathrm{X}^{\mathrm{T}}$ from closely related type strains was a positive Voges-Proskauer test.

A nearly complete $16 \mathrm{~S}$ rRNA gene fragment $(1500 \mathrm{nt})$ of strain $\mathrm{T}-16 \mathrm{X}^{\mathrm{T}}$ was amplified by PCR according to the protocol described by Katsivela et al. (1999). The purified PCR product was sequenced as described previously (Ahmed et al., 2007). The consensus sequence obtained using the DNASIS Pro software package (Hitachi Software Engineering) was compared with the sequences of closely related type strains retrieved from the DDBJ/EMBL database using BLAST searches. An alignment was produced using CLUSTAL X 1.8 software (Thompson et al., 1997) and edited using the BioEdit software package (Hall, 1999) to exclude ambiguous positions and gaps from the calculations. Ultimately, $1302 \mathrm{bp}$ were used to calculate evolutionary distances and $K_{\text {nuc }}$ values (Kimura, 1980) and to construct a phylogenetic tree using the neighbour-joining method (Saitou \& Nei, 1987) in the PHYLIP software package (Felsenstein, 2005). The tree was plotted using NJplot software. To assess the stability of the phylogenetic tree, a bootstrap analysis (Felsenstein, 2005) was performed using 1000 resamplings of the neighbour-joining data. Phylogenetic trees were also generated using maximum-likelihood and maximum-parsimony algorithms, which generated relationships for the novel strain similar to those constructed using the neighbour-joining method (Supplementary Fig. S3). These analyses strongly support the affiliation of strain $\mathrm{T}-16 \mathrm{X}^{\mathrm{T}}$ with the genus Gracilibacillus.

Based on the comparison of $16 \mathrm{~S}$ rRNA gene sequence data, the highest similarity of strain $\mathrm{T}-16 \mathrm{X}^{\mathrm{T}}$ was $96.7 \%$ with Gracilibacillus orientalis $\mathrm{XH}-63^{\mathrm{T}}$, followed by $95.5 \%$ with $G$. halotolerans $\mathrm{NN}^{\mathrm{T}}, 95.4 \%$ with $G$. dipsosauri $\mathrm{DD}^{\mathrm{T}}$ and 95.7\% with Paraliobacillus ryukyuensis $015-7^{\mathrm{T}}$. Strain $\mathrm{T}-16 \mathrm{X}^{\mathrm{T}}$ was associated with 'Bacillus group 1' in the subgroup of halophilic or halotolerant organisms as described by Ash et al. (1991) and formed a clade with G. orientalis $\mathrm{XH}-63^{\mathrm{T}}$ at a $64 \%$ bootstrap value (Fig. 1). The phylogenetic

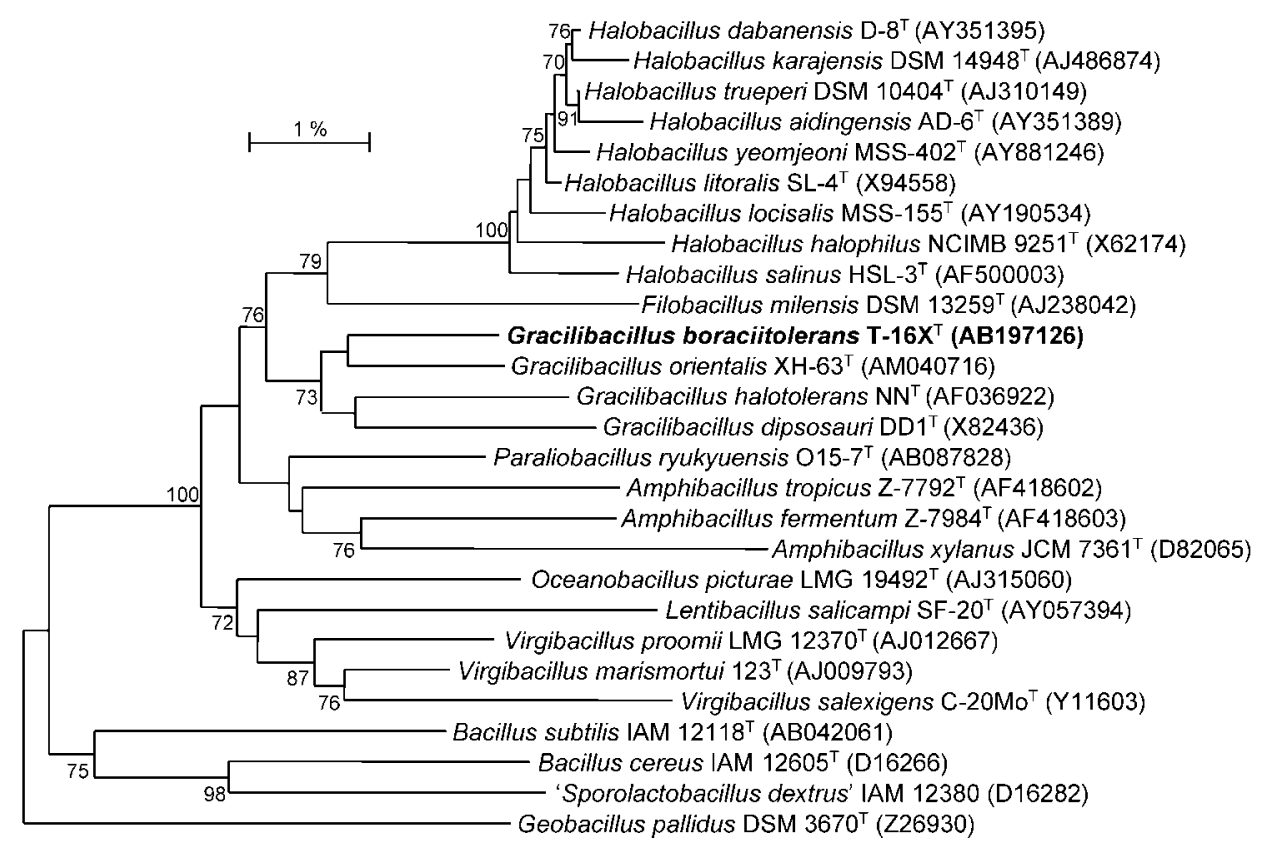

Fig. 1. Phylogenetic tree showing the interrelationships of strain $T-16 X^{\top}$ and closely related previously described species inferred from 16S rRNA gene sequences. The tree was constructed using the neighbour-joining method contained in the PHYLIP software package (Felsenstein, 2005), based on a comparison of approximately $1302 \mathrm{bp}$, and plotted using NJplot. Bootstrap percentages $\geqslant 70 \%$ from 1000 replications are given at branching points. Geobacillus pallidus DSM $3670^{\top}$ is the outgroup. Bar, $1 \%$ sequence divergence. 
position of strain $\mathrm{T}-16 \mathrm{X}^{\mathrm{T}}$ with G. orientalis was also supported by cellular fatty acid profiles (Table 2 ), in addition to other physiological and chemotaxonomic data.

Whole-cell fatty acid profiles for strain $\mathrm{T}-16 \mathrm{X}^{\mathrm{T}}$ and $G$. orientalis CCM $7326^{\mathrm{T}}$ were analysed from freeze-dried cell material grown in marine broth 2216 (MB; Difco) or MB plus $1.5 \% \mathrm{NaCl}$ for $24 \mathrm{~h}$ using the GC-based Microbial Identification system (MIDI) according to the manufacturer's instructions. The fatty acid profile of strain $\mathrm{T}-16 \mathrm{X}^{\mathrm{T}}$ was composed predominantly of branched-chain fatty acids, with anteiso- $\mathrm{C}_{15: 0}(45.7 \%)$ as the major fatty acid, followed by iso- $\mathrm{C}_{15: 0}(18.2 \%)$, anteiso- $\mathrm{C}_{17: 0}(16.9 \%)$ and iso- $\mathrm{C}_{17: 0}$ $(3.2 \%)$. Thus, it differed from G. halotolerans, in which iso- $\mathrm{C}_{17: 0}$ is absent. The fatty acid profile was quite similar to those of other members of Gracilibacillus, especially G. orientalis, in that it contained the same components, but in slightly different amounts (Table 2). Its phylogenetic position (Fig. 1) was also closely associated with G. orientalis. Halobacillus species possess the unsaturated fatty acids $\mathrm{C}_{16: 1} \omega 7 c$ alcohol and $\mathrm{C}_{17: 1} \omega 10 c$, which were absent from the profiles of strain $\mathrm{T}-16 \mathrm{X}^{\mathrm{T}}$ and other members of Gracilibacillus.

MK-7 (90\%) was determined to be the predominant respiratory quinone system in the novel strain using the method described by Xie \& Yokota (2003), although MK-6 $(10 \%)$ was also detected as a minor component. Cell-wall peptidoglycans were analysed for amino acid content using two-dimensional TLC and HPLC (Shimadzu) as described elsewhere (Schleifer \& Kandler, 1972; Groth et al., 1996). The peptidoglycans of strain $\mathrm{T}-16 \mathrm{X}^{\mathrm{T}}$ contained glutamic acid, meso-diaminopimelic acid, alanine and muramic acid in the molar ratio of $1.0: 1.1: 2.0: 0.4$ as the diagnostic amino acids, representing peptidoglycan type $\mathrm{A} 1 \gamma$ (directly cross-linked meso-diaminopimelic acid; Schleifer \& Kandler, 1972). The polar lipids were extracted and purified from $100 \mathrm{mg}$ dried cells by the procedure of Minnikin et al. (1984) and examined by two-dimensional TLC, using Kieselgel $60 \mathrm{~F}_{254}$ plates (Merck), as described by Kudo (2001). The polar lipid profile of strain $\mathrm{T}-16 \mathrm{X}^{\mathrm{T}}$ consisted predominantly of diphosphatidylglycerol and

Table 2. Cellular fatty acid compositions of strain $T-16 X^{\top}$ and closely related species

Values are percentages of total fatty acids; only fatty acids comprising $>0.5 \%$ of the total in at least one strain are included. Data for $G$. dipsosauri and G. halotolerans are from Wainø et al. (1999). tr, Trace amount; ND, not detected/not reported.

\begin{tabular}{|c|c|c|c|c|c|}
\hline Fatty acid & \multicolumn{2}{|r|}{$\mathrm{T}-16 \mathrm{X}^{\mathrm{T}}$} & $\frac{\text { G. orientalis CCM } 7326^{\mathrm{T}}}{\mathrm{MB}+1.5 \% \mathrm{NaCl}}$ & $\frac{\text { G. dipsosauri DSM } 11125^{\mathrm{T}}}{\mathrm{MB}}$ & $\frac{\text { G. halotolerans DSM } 11805^{\mathrm{T}}}{\mathrm{MB}}$ \\
\hline $\mathrm{C}_{14: 0}$ & 0.7 & 0.8 & 0.6 & $\operatorname{tr}$ & $\operatorname{tr}$ \\
\hline $\mathrm{C}_{15: 0}$ & 1.9 & 2.0 & 1.0 & 2.8 & 6.6 \\
\hline $\mathrm{C}_{16: 0}$ & 5.3 & 5.6 & 9.8 & 16.4 & 14.9 \\
\hline \multicolumn{6}{|l|}{ Branched-chain } \\
\hline iso- $\mathrm{C}_{14: 0}$ & 0.6 & 0.6 & 1.3 & $\operatorname{tr}$ & 4.1 \\
\hline iso- $\mathrm{C}_{15: 0}$ & 18.2 & 14.5 & 6.4 & 27.8 & 8.2 \\
\hline anteiso- $\mathrm{C}_{15: 0}$ & 45.7 & 50.8 & 39.0 & 29.7 & 40.9 \\
\hline iso- $\mathrm{C}_{16: 0}$ & 1.9 & 1.8 & 3.8 & 3.3 & 7.1 \\
\hline \multicolumn{6}{|l|}{ Unsaturated } \\
\hline $\mathrm{C}_{16: 1} \omega 7 c$ alcohol & ND & 0.1 & 0.8 & ND & ND \\
\hline $\mathrm{C}_{16: 1} \omega 11 c$ & 0.2 & 0.3 & 2.3 & $\operatorname{tr}^{*}$ & $3.0^{*}$ \\
\hline $\mathrm{C}_{18: 1} \omega 9 c$ & 1.0 & 0.5 & 0.7 & $\mathrm{ND}$ & $5.2 \dagger$ \\
\hline \multicolumn{6}{|l|}{ Summed features $\ddagger$} \\
\hline 3 & 0.6 & 0.5 & 0.5 & ND & ND \\
\hline 5 & 0.9 & 0.6 & $\mathrm{ND}$ & ND & ND \\
\hline
\end{tabular}

${ }^{\star}$ This component was identified only as $\mathrm{C}_{16: 1}$ by Wainø et al. (1999).

$\dagger$ This component was reported by Wainø et al. (1999) as the sum of two unidentified isomers of $\mathrm{C}_{18: 1}$, which were resolved as two components (2.73 and $2.45 \%)$.

$\ddagger$ Summed features are groups of two or three fatty acids that cannot be resolved by GLC using the MIDI System. Summed feature 3 contained iso- $\mathrm{C}_{15: 0} 2-\mathrm{OH}$ and/or $\mathrm{C}_{16: 1} \omega 7 c$. Summed feature 5 contained iso- $\mathrm{C}_{17: 0} \mathrm{I}$ and/or anteiso- $\mathrm{C}_{17: 0} \mathrm{~B}$. 
phosphatidylglycerol (Supplementary Fig. S4). An unknown aminolipid (AL1) and three unknown polar lipids (L1, L2, L3) were also detected, which could not be identified with any of the specific spray reagents employed. However, no reagent for detection of glycolipids was used. The type species of the genus, G. halotolerans, was also diagnosed with MK-7 as the predominant respiratory quinone system, meso-diaminopimelic acid in cell-wall peptidoglycans of type $\mathrm{A} 1 \gamma$ and the major polar lipids diphosphatidylglycerol and phosphatidylglycerol (Wainø et al., 1999) and hence these characteristics of strain $\mathrm{T}-16 \mathrm{X}^{\mathrm{T}}$ are in accordance with the traits of the genus Gracilibacillus; however, the lack of phosphatidylethanolamine, an unknown phospholipid and two unknown aminophospholipids reported to be present in G. orientalis (Carrasco et al., 2006) distinguished strain $\mathrm{T}-16 \mathrm{X}^{\mathrm{T}}$ from its phylogenetic neighbour (Fig. 1). These characteristics also fit many other bacilli. Thus, they do not indicate that the strain is a member of Gracilibacillus.

The DNA G + C content of strain T- $16 \mathrm{X}^{\mathrm{T}}$ was $35.8 \mathrm{~mol} \%$ as determined using a procedure described previously (Ahmed et al., 2007). The other three species of the genus Gracilibacillus have $\mathrm{G}+\mathrm{C}$ contents in the range $37-39 \mathrm{~mol} \%$, which is slightly higher than that of strain $\mathrm{T}-16 \mathrm{X}^{\mathrm{T}}$. However, the highest 16S rRNA gene sequence similarity of strain $\mathrm{T}-16 \mathrm{X}^{\mathrm{T}}$ occurred with members of Gracilibacillus (Fig. 1), and critical analysis of other chemotaxonomic data (Table 1) also suggested that strain $\mathrm{T}-16 \mathrm{X}^{\mathrm{T}}$ belongs to the genus Gracilibacillus.

For DNA-DNA hybridization experiments, the genomic DNA of the novel strain and of the previously described closely related type strains was isolated using Qiagen Genomic-tip 500/G following the manufacturer's protocol, with a minor modification in which RNase $T_{1}$ was used in addition to RNase A. DNA-DNA reassociation was carried out as described by Ezaki et al. (1989) at $39^{\circ} \mathrm{C}$ with photobiotin-labelled DNA in Nunc 96-well microplates. The DNA-DNA relatedness values of strain $\mathrm{T}-16 \mathrm{X}^{\mathrm{T}}$ were $26.2 \%$ with $G$. orientalis CCM $7326^{\mathrm{T}}, 13.1 \%$ with $G$. halotolerans DSM $11805^{\mathrm{T}}, 15.2 \%$ with G. dipsosauri DSM $11125^{\mathrm{T}}$ and $16.2 \%$ with Paraliobacillus ryukyuensis IAM $15001^{\mathrm{T}}$. These values were lower than the threshold of $70 \%$ and thus indicate that strain $\mathrm{T}-16 \mathrm{X}^{\mathrm{T}}$ represents a novel species (Stackebrandt \& Goebel, 1994). The morphological, chemotaxonomic, phylogenetic and genotypic features of strain $\mathrm{T} 16 \mathrm{X}^{\mathrm{T}}$ suggest that it belongs to the genus Gracilibacillus; we propose the name Gracilibacillus boraciitolerans sp. nov.

\section{Description of Gracilibacillus boraciitolerans sp. nov.}

Gracilibacillus boraciitolerans (bo.ra'ci.i.to'le.rans. N.L. n. boracium boron; L. part. adj. tolerans tolerating; N.L. part. adj. boraciitolerans boron-tolerating).

Cells are motile using a long monotrichous flagellum. Cells are Gram-positive, short rods, $2.0-4.5 \mu \mathrm{m}$ in length,
$0.3-0.9 \mu \mathrm{m}$ in diameter, occurring singly, occasionally in pairs; filamentous cells also occur. Spherical endospores are produced in a non-swollen or slightly swollen sporangium in a terminal or subterminal position. Colonies are circular with entire margins, spreading but slightly convex, translucent and viscous in texture, $2-3 \mathrm{~mm}$ in diameter after 4 days growth on BUG agar medium $(\mathrm{pH} 7.5)$ at $30^{\circ} \mathrm{C}$. Younger colonies are dirty white, but become pink and then red in a few to several days. The pink or red pigment may diffuse into the agar medium after several days. Colonies are mostly light pink at high salt concentrations. Grows optimally at $25-28^{\circ} \mathrm{C}$; the temperature range for growth is $16-37^{\circ} \mathrm{C}$; no growth occurs at $\geqslant 45^{\circ} \mathrm{C}$ and little growth at $16^{\circ} \mathrm{C}$ after several days. The optimum $\mathrm{pH}$ for growth is 7.5-8.5, with a range of $\mathrm{pH} 6.0-10.0$. The type strain can tolerate $0-450 \mathrm{mM}$ boron, but grows optimally in the absence of boron. The $\mathrm{NaCl}$ tolerance range is $0-11 \%(\mathrm{w} / \mathrm{v})$, indicating that the type strain is moderately halotolerant; it can grow on MA, TSA and NA (with or without boron or $\mathrm{NaCl}$ ). Oxidase, catalase, Voges-Proskauer and $o$-nitrophenyl $\beta$-D-galactopyranoside (ONPG) tests are positive, whereas tests for production of indole and $\mathrm{H}_{2} \mathrm{~S}$, nitrate reduction, lysine and ornithine decarboxylases, arginine dihydrolase, tryptophan deaminase, utilization of citrate and hydrolysis of gelatin and urea are negative (API 20E). Can produce acid from L-arabinose, D-ribose, glucose, D-mannose, aesculin, D-cellobiose, D-maltose, D-lactose, D-melibiose and D-trehalose; weakly positive for acid production from $\mathrm{D}$-xylose, methyl $\beta$-D-xylopyranoside, D-fructose, D-mannitol and D-sorbitol (API 50CHB). Can oxidize 3-methyl glucose, amygdalin, arbutin, D-cellobiose, dextrin, D-fructose, D-galactose, D-mannitol, D-mannose, D-melezitose, D-melibiose, D-psicose, D-raffinose, D-ribose, D-sorbitol, D-trehalose, D-xylose, gentiobiose, glycerol, lactulose, L-arabinose, maltose, maltotriose, palatinose, salicin, sucrose, turanose, $\alpha$-D-glucose, $\alpha$-D-lactose, methyl $\alpha$-D-galactoside, methyl $\beta$-D-galactoside, methyl $\alpha$-D-glucoside, methyl $\beta$-D-glucoside, DL-lactic acid, D-glucuronic acid, gluconic acid, pyruvic acid and $\alpha$-ketobutyric acid (Biolog). The major cellular fatty acids are: anteiso- $\mathrm{C}_{15: 0}$ $(45.7 \%)$, iso- $\mathrm{C}_{15: 0}(18.2 \%)$, anteiso- $\mathrm{C}_{17: 0}(16.9 \%)$, iso$\mathrm{C}_{17: 0}(3.2 \%), \mathrm{C}_{16: 0}(5.3 \%), \mathrm{C}_{15: 0}(1.9 \%)$, iso- $\mathrm{C}_{16: 0}$ $(1.9 \%), \mathrm{C}_{18: 1} \omega 9 c(1.0 \%)$ and traces (less than $\left.1 \%\right)$ of some other fatty acids. The cell wall contains peptidoglycan with meso-diaminopimelic acid as the diagnostic amino acid, representing cell-wall peptidoglycan type A1 $\gamma$. The dominant respiratory lipoquinone system is MK-7. Major polar lipids are diphosphatidylglycerol and phosphatidylglycerol. In addition, moderate to minor amounts of an unknown aminolipid and three polar lipids are detected. Strong enzyme activity is observed for alkaline phosphatase, $\beta$-galactosidase and $\alpha$ - and $\beta$-glucosidase, whereas weak enzyme activity is observed for $\alpha$-galactosidase, esterase (C8), esterase lipase (C8) and leucine arylamidase (API ZYM). Resistant to penicillin, amoxicillin and metronidazol (ATB-VET Strip). The $\mathrm{G}+\mathrm{C}$ content of the type strain is $35.8 \mathrm{~mol} \%$ (HPLC). 
Strain T-16X $\mathrm{X}^{\mathrm{T}} \quad\left(=\mathrm{DSM} \quad 17256^{\mathrm{T}}=\mathrm{IAM} \quad 15263^{\mathrm{T}}=\right.$ ATCC BAA- $1190^{\mathrm{T}}$ ), which was isolated from soil naturally containing boron minerals from the Hisarcik area in the Kutahya Province of Turkey, is the type strain.

\section{Acknowledgements}

We thank Dr Cavit Çöl for collecting soil samples from the Hisarcik area (Turkey), Dr Atsushi Yamazoe for providing help and technical guidance for the Biolog experiment, Mr Tsutomu Negishi (JEOL Ltd, Tokyo) for help with the scanning electron micrographs and Drs M. Suzuki and N. Bughio for providing valuable comments on the manuscript.

\section{References}

Ahmed, I., Yokota, A. \& Fujiwara, T. (2007). A novel highly boron tolerant bacterium, Bacillus boroniphilus sp. nov., isolated from soil, that requires boron for its growth. Extremophiles 11, 217-224.

Ash, C., Farrow, J. A. E., Wallbanks, S. \& Collins, M. D. (1991). Phylogenetic heterogeneity of the genus Bacillus revealed by comparative analysis of small-subunit-ribosomal RNA sequences. Lett Appl Microbiol 13, 202-206.

Carrasco, I. J., Márquez, M. C., Xu, Y., Ma, Y., Cowan, D. A., Jones, B. E., Grant, W. D. \& Ventosa, A. (2006). Gracilibacillus orientalis sp. nov., a novel moderately halophilic bacterium isolated from a salt lake in Inner Mongolia, China. Int J Syst Evol Microbiol 56, 599-604.

Chen, X., Schauder, S., Potier, N., Van Dorsselaer, A., Pelczer, I., Bassler, B. L. \& Hughson, F. M. (2002). Structural identification of a bacterial quorum-sensing signal containing boron. Nature 415, 545-549.

Cochran, D. G. (1995). Toxic effects of boric acid on the German cockroach. Experientia 51, 561-563.

Çöl, M. \& Çöl, C. (2003). Environmental boron contamination in waters of the Hisarcik area in the Kutahya Province of Turkey. Food Chem Toxicol 41, 1417-1420.

Cowan, S. T. (1974). Manual for the Identification of Medical Bacteria. Cambridge: Cambridge University Press.

Deutch, C. E. (1994). Characterization of a novel salt-tolerant Bacillus sp. from the nasal cavities of desert iguanas. FEMS Microbiol Lett 121, 55-60.

Ezaki, T., Hashimoto, Y. \& Yabuuchi, E. (1989). Fluorometric deoxyribonucleic acid-deoxyribonucleic acid hybridization in microdilution wells as an alternative to membrane filter hybridization in which radioisotopes are used to determine genetic relatedness among bacterial strains. Int J Syst Bacteriol 39, 224-229.

Felsenstein, J. (2005). PHYLIP - Phylogeny Inference Package, version 3.6. Distributed by the author. University of Washington, Seattle, WA, USA.

Groth, I., Schumann, P., Weiss, N., Martin, K. \& Rainey, F. A. (1996). Agrococcus jenensis gen. nov., sp. nov., a new genus of actinomycetes with diaminobutyric acid in the cell wall. Int J Syst Bacteriol 46, 234-239.

Hall, T. A. (1999). BioEdit: a user-friendly biological sequence alignment editor and analysis program for Windows 95/98/NT. Nucleic Acids Symp Ser 41, 95-98.

Irschik, H., Schummer, D., Gerth, K., Hofle, G. \& Reichenbach, H. (1995). The tartrolons, new boron-containing antibiotics from a myxobacterium, Sorangium cellulosum. J Antibiot 48, 26-30.
Jones, B. E., Grant, W. D., Collins, N. C. \& Mwatha, W. E. (1994). Alkaliphiles: diversity and identification. In Bacterial Diversity and Systematics, pp. 195-230. Edited by F. G. Priest, A. RamosCormenzana \& B. J. Tindall. New York: Plenum.

Katsivela, E., Bonse, D., Krüger, A., Strömpl, C., Livingston, A. \& Wittich, R.-M. (1999). An extractive membrane biofilm reactor for degradation of 1,3-dichloropropene in industrial waste water. Appl Microbiol Biotechnol 52, 853-862.

Kimura, M. (1980). A simple method for estimating evolutionary rates of base substitutions through comparative studies of nucleotide sequences. J Mol Evol 16, 111-120.

Kohno, J., Kawahata, T., Otake, T., Morimoto, M., Mori, H., Ueba, N., Nishio, M., Kinumaki, A., Komatsubara, S. \& Kawashima, K. (1996). Boromycin, an anti-HIV antibiotic. Biosci Biotechnol Biochem 60, 1036-1037.

Kudo, T. (2001). Phospholipids. In Identification Manual of Bacteria: Molecular Genetics and Molecular Biological Methods, pp. 135-144. Edited by K. Suzuki, A. Hiraishi \& A. Yokota. Tokyo: Springer Verlag. Lawson, P. A., Deutch, C. E. \& Collins, M. D. (1996). Phylogenetic characterization of a novel salt-tolerant Bacillus species: description of Bacillus dipsosauri sp. nov. J Appl Bacteriol 81, 109-112.

Minnikin, D. E., O’Donnell, A. G., Goodfellow, M., Alderson, G., Athalye, M., Schaal, A. \& Parlett, J. H. (1984). An integrated procedure for the extraction of bacterial isoprenoid quinones and polar lipids. J Microbiol Methods 2, 233-241.

Nable, R. O., Bañuelos, G. S. \& Paull, J. G. (1997). Boron toxicity. Plant Soil 193, 181-198.

Negrete-Raymond, A. C., Weder, B. \& Wackett, L. P. (2003). Catabolism of arylboronic acids by Arthrobacter nicotinovorans strain PBA. Appl Environ Microbiol 69, 4263-4267.

Nielsen, F. H. (2004). Boron. In Elements and their Compounds in the Environment, 2nd edn, pp. 1251-1260. Edited by E. Merian, M. Anke, M. Ihnat \& M. Stoeppler. Weinheim: Wiley-VCH.

Otero, L., Palacio, V., Mendez, F. J. \& Vazquez, F. (2002). Boric acid susceptibility testing of non-C. albicans Candida and Saccharomyces cerevisiae: comparison of three methods. Med Mycol 40, 319-322.

Rowe, R. I. \& Eckhert, C. D. (1999). Boron is required for zebra fish embryogenesis. J Exp Biol 202, 1649-1654.

Rowe, R. I., Bouzan, C., Nabili, S. \& Eckhert, C. D. (1998). The response of trout and zebra fish embryos to low and high boron concentrations is U-shaped. Biol Trace Elem Res 66, 262-270.

Saitou, N. \& Nei, M. (1987). The neighbor-joining method: a new method for reconstructing phylogenetic trees. Mol Biol Evol 4, 406-425.

Schleifer, K. H. \& Kandler, O. (1972). Peptidoglycan types of bacterial cell walls and their taxonomic implications. Bacteriol Rev 36, 407-477.

Stackebrandt, E. \& Goebel, B. M. (1994). Taxonomic note: a place for DNA-DNA reassociation and 16S rRNA sequence analysis in the present species definition in bacteriology. Int J Syst Bacteriol 44, 846-849.

Stanier, R. Y., Palleroni, N. J. \& Doudoroff, M. (1966). The aerobic pseudomonads: a taxonomic study. J Gen Microbiol 43, 159-271.

Swate, T. E. \& Weed, J. C. (1974). Boric acid treatment of vulvovaginal candidiasis. Obstet Gynecol 43, 893-895.

Thompson, J. D., Gibson, T. J., Plewniak, F., Jeanmougin, F. \& Higgins, D. G. (1997). The CLUSTAL_X windows interface: flexible strategies for multiple sequence alignment aided by quality analysis tools. Nucleic Acids Res 25, 4876-4882.

Wainø, M., Tindall, B. J., Schumann, P. \& Ingvorsen, K. (1999). Gracilibacillus gen. nov., with description of Gracilibacillus 
halotolerans gen. nov., sp. nov.; transfer of Bacillus dipsosauri to Gracilibacillus dipsosauri comb. nov., and Bacillus salexigens to the genus Salibacillus gen. nov., as Salibacillus salexigens comb. nov. Int J Syst Bacteriol 49, 821-831.
Warington, K. (1923). The effect of boric acid and borax on the broad bean and certain other plants. Ann Bot 37, 629-672.

Xie, C. \& Yokota, A. (2003). Phylogenetic analysis of Lampropedia hyalina based on the 16S rRNA gene sequence. J Gen Appl Microbiol 49, 345-349. 